\title{
त्री \\ A ruptura articulatória dos seres: a propósito da exposição da vida à dispersão da sua ontologia
}

Jorge Leandro RosA

\begin{abstract}
禺
RESUMO

Este artigo trata da possibilidade de renovar o entendimento da eugenia no mundo contemporâneo. A biologia e a genética são fontes científicas da eugenia, mas não fazem parte de seu núcleo filosófico. Essa é a razão pela qual vemos a ontologia subjacente à eugenia como nossa principal preocupação. $\mathrm{O}$ estatuto da eugenia como uma prática está mudando rapidamente e a vida é tanto o objeto como a dimensão oculta dessa mudança. Entendida por meio da história dos seres, a dispersão da ontologia permite um entendimento renovado tanto da humanidade quanto da animalidade. Como se pode entender que uma ciência completamente reconhecida no início do século xx se tenha tornado uma prática silenciosa no século xxi? A disseminação das novas técnicas genéticas e a discrição atual acerca da eugenia parecem estar ligadas ao avanço de sua reabilitação. Ainda estamos em um estágio inicial de nosso entendimento da genética humana. Não há razão para pensar que esse conhecimento não será explorado pela eugenia. A plasticidade de nossa condição humana encontra nisso uma de suas possibilidades.
\end{abstract}

PalaVras- Ghave • Eugenia. Ontologia. Vida.

As ciências da vida tornaram-se um campo de grande complexidade, já distante do tempo em que Lamarck (1802) propunha a designação de "biologia" para aquela parte da investigação científica que não estivesse determinada pelo exercício da medicina. Daí que a expressão "ciências da vida" seja, ao mesmo tempo, reflexo de uma pluralidade crescente, mas também sinal persistente da mais resiliente singularidade com que a filosofia se confronta ainda hoje: a vida. Em consequência, incluímos aí quer domínios clássicos da zoologia, da botânica, da agronomia, quer aqueles da neurologia, da química molecular, das biotecnologias, das ciências genéticas e mesmo da eugenia. Esses domínios científicos e tecnocientíficos, laboratórios da própria reorientação da convergência entre ciência e técnica, formam hoje o campo do conhecimento humano 
mais capaz de profundamente alterar as condições e o sentido daquela existência humana que entendíamos, até recentemente, como equidistante da vida e da cultura.

A singularidade do vivo é, atualmente, não apenas um desafio ao trabalho filosófico, já que nela há uma exigência de pensamento que procura o conceito, mas também um elemento teleológico e instrumental constantemente presente nas próprias transformações epistemológicas e tecnológicas que emergem nas ciências da vida. A vida é ainda um mistério, se tentarmos compreender o que ela é no limite que a nega, sendo esse tal mistério ativamente deslocado pelas múltiplas possibilidades que se abrem quando a prolongamos, hibridamos ou adaptamos. Cada vez mais, a vida deixa de estar fixada à dotação de todo o ser humano com um rosto, para passar a circular como uma escrita que transborda o indivíduo. A eugenia, que será questão neste texto, é sinal dessa deslocação da vida. No último século, ela foi abandonando o princípio da figuração da vida, para dela passar a fornecer modificações que se querem silenciosas e não aparentes. Ora, sem aparência não há ontologia pensável. A discrição da eugenia corresponde, neste seu regresso, ao trabalho silencioso das ontologias, a sua dispersão.

A dispersão ontológica do conceito de vida, a que o título faz referência, parece não tomar em conta as inúmeras similitudes que as ciências têm vindo a descobrir nas mais diversas formas de vida. De algum modo, essas similitudes poderiam aproximarnos de um quadro estabilizado da vida. Alguns poderiam mesmo ver aí a reemergência pós-teológica da singularidade ontológica do vivo. Mas como a vida não é, filosoficamente falando, o mesmo que a biologia ou a genética - e como esse estado supõe sempre que algo imprevisível acontece -, haverá a necessidade de nos interrogarmos sobre a situação contemporânea daquilo que chamamos a "vida" dos entes. Depois de ter estado ao serviço do ser e das suas escalas, a vida passou a servir as biotecnologias aplicadas às espécies, tomando, entretanto, o cuidado de preservar a sua qualificação "médica" no caso dos humanos. Na verdade, são as similitudes dos seres que motivam o regresso de práticas de recomposição e recombinação dos seres vivos, que hoje se manifestam na transversalidade que as ciências da vida abrem no espectro desses seres. ${ }^{\mathbf{1}} \mathrm{O}$ nosso conhecimento do vivo aprofunda, necessariamente, a sua exaustividade, já que vastas reservas de materiais biológicos estão em vias de serem identificadas nas diversas espécies. Há, portanto, em paralelo, uma urgência econômica em demonstrar a similitude dos seres vivos, mas a eugenia associa-se aqui à dispersão das ontologias dos entes, a fim de abrir a porta a novas configurações simbólicas do vivo, que ela sabe incontornáveis.

1 O plural "seres" marca uma oscilação que explícita e implicitamente percorre o nosso texto: usual na linguagem quotidiana e também nas referências aos fenômenos da vida, como em "seres humanos" ou "seres vivos", ele é inusitado no domínio da ontologia, já que o ser é definido pela sua forma singular, "o ser". Plurais são os "entes". Julgamos que o tema da "dispersão da ontologia" que aqui introduzimos será pensável através do emprego inadequado deste vocábulo. 
Nada disso distingue hoje as ciências da vida da situação das outras ciências. Essa seria, aliás, uma primeira acepção da dispersão ontológica: o vivo e o não vivo parecem submeter-se a um grau equivalente de manipulação das suas estruturas. Ambas as categorias são colocadas na posição do "recurso disponível" ou, usando o termo empregado por Heidegger, são conduzidas a sua "manifestação como fundo" (Heidegger, 199o, p. 43). Mas a questão da vida permanece intratável. Ela não é o objeto das ciências da vida, mas o seu escândalo, quer dizer, o seu tópico inquietante, a que elas não podem eximir-se, mas sobre o qual não lhes cumpre formular um discurso ou mesmo uma definição. Assim, mesmo considerando que todo o real é transportado ao dispositivo (Gestell), ${ }^{2}$ permanece em aberto o problema da vida, razão pela qual consideraremos que a dispersão da sua ontologia não se reduz à questão do estatuto do real investido pela tecnociência.

A vida permanece aquilo que necessita de ser interrogado, já que ela não se confunde, nem com o processo econômico, nem com a determinação da identidade. Essa indeterminação da vida, persistente e incompreensível, conduziu à determinação política do ser humano, como acontece já em Platão. ${ }^{3}$ Será preciso acrescentar que a determinação política do humano é indissociável da convocação à dominação política das outras espécies, convocação que se torna mais clara pela ação da tecnociência, mas que Platão já aventara claramente ao referir-se à guerra civil (stasis) que grassou longamente entre os homens e os animais. ${ }^{4}$ Ao contrário do que seria de esperar, a dispersão ontológica foi o corolário filosófico do encerramento dessa guerra civil. Na dispersão ontológica, verificamos que nada da situação dos seres vivos no mundo pode ser explicado pelo simples fato de nele terem aparecido. A vida não está fundada no mundo, porque ela não é o resultado concludente da exposição de certos entes à existência. A vida não cabe em uma ontologia que determina, desde logo, o seu lugar no mundo. É por essa razão que a vida não coincide com o seu fundamento ontológico. Dito de outro modo, a existência de certos entes sofre uma indeterminação particular que é própria do fato de estarem vivos. Embora a tradição filosófica tenha tentado fixar ontologicamente a caracterização das espécies, estabelecendo, por exemplo, uma barreira entre humano e não humano, verificamos que a vida não respeita esses limites. O resultado não é apenas a plasticidade do vivo, mas a própria fragilidade da caracterização ontológica.

20 Gestell, que só muito aproximativamente pode ser "traduzido" como "estrutura", "dispositivo", sendo preferível a descrição "essência-dispositivo da técnica", proposta por Catherine Malabou (2004, p. 167), que, no nosso entendimento, é aquele conceito do "segundo Heidegger" que se aproxima negativamente da vida pela absoluta metamorfose de todos os entes em figura(s).

3 A ciência política é descrita por ele como "produção e criação de seres vivos" (Platão, 1994, p. 346).

4. "A política, portanto, começa verdadeiramente com a guerra civil que se desencadeia entre as espécies quando os deuses abandonam o governo direto do mundo" (Romandini, 2010a, p. 23). 
Não estando aqui em questão uma sobredeterminação da "vida", interessa-nos revelar aquilo que excede as práticas tecnocientíficas que tomam o vivo por objeto.

Em si mesma, a dispersão ontológica toca uma dimensão central da ontoteologia ocidental, que falhou ao afastar o conceito de vida do centro das nossas questões filosóficas sobre os entes em geral. "Dispersão" significa que certos traços da vida não correspondem necessariamente a certos órgãos, corpos, morfologias ou funções. $\mathrm{Na}$ medida em que as singularidades dos seres vivos são atravessadas por técnicas que as reorganizam, mais a sua vida aparece como evidência inultrapassável e ontologicamente dispersa. Nos tópicos que nos interessam, levantaremos as questões ontológicas da coesão e da singularidade. Reunidas em uma mesma pergunta, elas parecem conduzir a uma contradição, qual seja, enquanto a coesão metafísica conduz, na maior parte dos casos, à afirmação de universais, já que os entes parecem tocar a sua essência se pertencerem a classes ou a espécies, a questão da singularidade viva leva-nos a colocar os princípios da individuação ou da essência individual do que existe. Contudo, é verificável que os entes vivos estão ligadose são singulares. Assim, é necessário que alguma estrutura ontológica possa assegurar que eles se mantenham ligados entre si, mas também diferenciáveis entre si, porque singulares e automotivados. Essa estrutura não é necessariamente estável, mas pode comportar uma plasticidade decisiva. Poderemos chamar-lhe vida? A essa plasticidade parecem recorrer cada vez mais os processos tecnocientíficos atuais. A indagação filosófica deve, por seu turno, encontrar nela uma nova exigência de sentido que, estando atenta a esses processos, deles é independente.

Dizendo-o de um modo sucinto, o que as biotecnologias atualmente fazem é, do ponto de vista histórico-filosófico, a produção de um impensado radical a que todos somos convocados. Embora o predomínio do humano apareça mais e mais perigoso para todas as outras formas de vida, é pela destruição das barreiras metafísicas erguidas entre eles e os outros seres vivos que os próprios humanos redefinem e alargam as possibilidades que sustentam as suas vidas. Se o modelo clássico era aquele que propunha a assunção de uma vida humana, o modelo biotecnológico propõe simplesmente a vida ao humano. Põe-se, afinal, o problema da apropriação do vivo. Há uma vida entendida como capital e apenas ela parece capaz de redefinir a economia em uma acepção muito próxima do seu modelo capitalista, já que apenas ele joga ainda com uma concepção do valor ilimitadamente disponível. É certo que as nossas sociedades valorizam a preservação da vida para além do que conhecemos em qualquer outro contexto. As vidas inviáveis são salvas, as vidas doentes são prolongadas, as vidas hipotéticas são criadas. Há um valor-vida que nos mobiliza, embora não se possa dizer que ele seja, constantemente, o "valor da vida", tal como as tradições cristã e humanista o declinaram. Nessas concepções, os seres vivos nascem, ou seja, acedem a uma singularidade inexplicável a partir do material biológico em que são constituídos. No valor-vida, 
os vivos são produzidos a partir de processos que podem ser descritos. O valor-vida é profundamente característico da autorregulação dos processos técnicos, já que ele é relançado, não por uma ideia ética e/ou teológica da vida, mas pela própria necessidade de uma eficácia de que ela é o referente. Jacques Ellul (1977) colocou com agudeza esse problema: a técnica serve sempre a sua própria possibilidade operativa. Para conseguir fazê-lo, ela deverá ampliar constantemente as suas articulações possíveis.

Todos os entes, pela sua presença no mundo (cf. Heidegger, 1995, § 42-48), estão em articulação com outros entes. Essa situação pode apresentar inúmeras variantes e satisfaz a questão ontológica, ela mesma, que a generalidade dos entes se coloca ou coloca aos outros entes. Diremos, contudo, que há duas variantes em que a articulação com os outros entes é problemática e apresenta-se fissurada desde o princípio entre

(1) o ente humano tomado na sua existência singular, no duplo sentido do termo, e

(2) o ente humano diante do ente técnico.

Não importa tanto discutir se há aí uma relação genealógica, produtiva, paleontológica ou outra entre ambos os casos. Mas coloca-se aqui um problema que merece a nossa atenção. Todos nós podemos, certamente, pensar o ente humano tomado em si mesmo, contudo é improvável que tenha existido um ente humano que não estivesse diante de algum ente técnico, que não estivesse investido em algum tipo de articulação com um ente técnico. Então, (1) é um caso que podemos claramente conceber, mas (2) é a efetiva (no sentido que explicitaremos abaixo) realização de (1). Arriscamos dizer que os entes técnicos apresentam-se determinantes para a qualidade humana dos entes apontados em (1), mas que são imediatamente circunscritos à esfera que se origina pela sua presença determinante.

Esses entes técnicos, contudo, articulam-se com todos os entes que o ente humano conhece (e provavelmente com alguns que ele não conhece verdadeiramente). Eles não só se articulam de muitos modos com outros entes, como o problema dessa articulação é aquilo que regressa incessantemente por uma acumulação que não depende apenas da variabilidade do ambiente, mas se origina na estranha duplicidade da constituição do humano por articulação autônoma e por articulação técnica. A primeira é sempre afirmativa quando o humano entra em contato com outros entes no plano epistêmico; a segunda é sempre "efeitual" (no sentido de effectus) quando há relação 
no plano ontológico. Esse ser humano diria: sei o que conheço, mas preciso "esquecer" a dívida que me liga a esse ente que só posso designar como técnico. O que significa que um ente técnico e um ente humano são duplamente constituídos pela articulação. Em primeiro lugar, porque a sofrem; em segundo, porque adicionam incessantemente novas articulações, constituindo um processo de esquecimento que não é "o esquecimento de", mas o "ser em esquecimento". Verificar-se-á que é aqui introduzida uma ação sem substância própria.

Essa estratificação das articulações determina a posição humana enquanto ser e assenta em uma fiç̧ão da sua presença, ou seja, se o ser está presente, como é o caso de (1), que acima referimos, aquilo em que se articula é a própria presença, sendo que a consequente afirmação de um reconhecimento do humano enquanto figura resulta problemática. Em (2), há uma efetiva resolução de (1), sem que a articulação "humano - ente técnico" possa adquirir uma relevância ontológica própria. Há em (2) um plano da articulação que se conserva maximamente atuante, mas que nunca chega à presença plena em sentido ontológico. Deixamos de lado a distinção praxis/techné, porque aquilo que discutimos não é a caracterização da finalidade do ato, mas essa incontornável presença de um ente que é in actum, mas não no ato tomado como próprio. Dando um salto, perguntaremos, que responsabilidade atribuímos a entes que estão desprovidos de seus atos, mas que são decisivos dos atos humanos? É a pergunta que deve ser colocada perante a enigmática dispersão pelo vivo da pergunta ontológica.

Essa questão, que tentamos aqui apresentar sob uma forma esquemática, ocorre a propósito do problema da eugenia. Como escreve John Glad, "a genética moderna é, historicamente, um derivado da eugenia, não o contrário" (2008, p. 13). "Eugenia" significa, na sua forma grega, "bem-nascido" e é um termo moderno cunhado por Francis Galton (1829-1894). Enquanto domínio característico da modernidade, haverá que explicitar que esse "bom nascimento" não pode ser confundido com os bemnascidos do passado. Em uma formulação aplicável à eugenia moderna e mais arriscada, declararíamos que desde que o homem nasce, a técnica ajuda-o a nascer como o que devém melhor. Como o humano só o pode ser pelo acontecimento decisivo que o faz aparecer - um nascimento - a presença incontornável da técnica tem consequências ontológicas quando o que ela faz é algo mais do que vencer a dificuldade do nascer. Quando um ente técnico me faz enquanto obra boa, ele entra na esfera do que sou, sem que eu possa vê-lo objetivamente. No seu sentido genético, o devir não pode aspirar à resolução formal do fabrico. Nascendo, o ente humano modificado está em uma negociação genética que resolve o nascer, que o torna, já não o acontecimento obscuro que obstaculiza a memória, mas o acidente pelo qual outro ente, espectral, nasceu com esse "humano". Ele é o efeito aí ocorrido. O que significa que os seres humanos nascem, mas os entes técnicos só podem nascer por meio do nascimento dos primeiros. Dada a 
nossa experiência de (1) e de (2), diríamos que os entes técnicos são amplamente dotados da possibilidade de nascerem pela sua presença actancial no nascimento de humanos. Perguntamos, então, que ente é esse que nasce conosco já que a sua posição determinante está articulada com o nascituro antes ainda do seu nascimento e durante este. Há aqui uma transformação da ontologia que vai além da estranha dupla variante (1) e (2) que apresentamos antes.

Recorde-se, a esse propósito, o exemplo literário da Metamorfose de Kafka. Ela é a narrativa de um nascimento submetido a uma operação não nomeada, mas cujo resultado está presente diante do leitor. Gregor não é um ser humano que passou a ser um inseto, mas é um inseto que, recordando a sua humanidade, a vai perdendo. Esse processo da recordação do que era entra em choque com o que acontece no presente narrativo. Há aí, portanto, um fator que age e que nasceu no momento em que Gregor passou a devir-animal. Gregor não está a tornar-se aquele ou este animal; ele está no devir instaurado por algo que não pode ser um escaravelho, mas que nunca se apresenta naquilo que coloca a personagem na sua metamorfose. O escaravelho é apenas a figura em que esse devir pode ser captado.

O perigo da técnica é a sua ligação à figura no processo da aparição do ontológico. É a figura que explode, que se faz catástrofe, não a técnica, que é o processo de sustentação da figura. Evidentemente, as adições que a técnica faz às suas articulações não são totalmente idênticas àquelas que o humano opera. Mas conhecem-se num ponto: as articulações que estabelecem, não apenas os sustentam, mas comprometem-nos no seu ser. Pela articulação, os processos técnicos e os homens não só se desagregam e recompõem, o que acontece ontologicamente a todos os entes, como se tornam seres excedentários relativamente a si mesmos. É aí que, ligado à técnica, o homem procura ser figura.

Tanto o ser humano como os entes técnicos são entes metafísicos que operam pela adição. Mas essa adição decorre desde sempre e não tem um resultado à vista. São entes capazes de manipular a programação, mas toda a programação que os vise é comprometida pela adição metafísica que os trabalha. O homem, por exemplo, é um ser vivo e não deixa de sê-lo pela manifestação da animalidade que se dá nele, vindo acrescentar-se a esta a voz (phoné), que não exclui nele o animal. Avoz, por sua vez, é investida pela linguagem discursiva (logos). Excedentes conhecidos e desconhecidos acumulamse nesses entes, sendo que o excedente nunca é inativo. Há, pois, essa parelha de entes, incapazes de deixar de adicionar(-se). Reconhecem-se um no outro, mas a junção de suas adições forma uma sobreposição inquietante. Há aqui um cobrimento (também em sentido sexual), uma zona de sombra, o que não permite que o homem traga a técnica à luz ou que esta dê a ver o humano nele. A articulação entre o homem e o ente técnico não é uma relação de ferramenta, mas de consum(açã)o: consome-se o ser consumindo-se no ser. 
Mais propriamente, na articulação eugênica com a técnica há algo que me retira, a mim que sou humano, à perversidade da relação entre (1) e (2). Há algo que está logicamente constituído na minha articulação ontológica com a técnica. Ora, se as operações propriamente técnicas devem conter uma referência à lógica, a sua presença ontológica no que eu sou não deveria aí caber. Se toda a história da técnica é a história em dobra do humano, na eugenia, a constituição em estratos do que sou tenderá necessariamente a resolver-se. A eugenia visa atingir o ser como figura. É essa a figura que consumo e que me vem consumir. Ser e práxis, obra e operação, reúnem-se no ato eugênico.

Nossa pergunta, neste ponto, é: o que acontece quando um ente que (se) adiciona faz-se objeto de outro que age segundo o mesmo princípio metafísico? Técnica e humano são articulações um do outro, o que é muito mais significativo do que o fato de serem objeto ou sujeito um do outro. Porque, enquanto articulação, cada um deles torna-se opaco perante o outro nas adições metafísicas que lhe incubem. E essa opacidade impossibilita que a condição de sujeito seja aí mais do que uma estrutura de repetição ou de amplificação. Diremos, assim, que a técnica é a captação do que é o resto do humano e que esse resto não é aí esquecido nem resolvido. Mas um ser sem resto, um ser irresolúvel, certamente, encontra uma frágil narrativa da resolução quando está diante de outro ser sem resto. É essa uma típica articulação teológica e partilha, decerto, a irresolução das relações ontoteológicas. Contudo, essa narrativa pode transformar-se em resolução efetiva quando se encontrar com um ato que possa ser tomado como decisivo do ponto de vista ontológico.

Referimos, em outro texto (cf. Rosa, 2009), a particular analítica agambeana da ontoteologia, renovada e prolongada agora em um livro recente, onde Agamben evoca a transformação que o esquema aristotélico da energia/dynamis sofre no pensamento cristão diante do ato técnico por excelência que é o ofício, a ação litúrgica. Como ele aí escreve, abre-se "o estatuto ontológico do ato litúrgico, do opus Dei, onde ser e práxis, efeitualidade e efeito, opus operatum e opus operans, entrelaçam-se de maneira inseparável" (Agamben, 2011, p. 67). As coisas e a operação são assim consideradas de modo inseparável na sua efetividade e na sua função como efeito: tal é a nova dimensão ontológica que vem substituir-se à energeia aristotélica. Essa transformação do agir encontra nos processos da eugenia, assim como no discurso que hoje a justifica, após a sua etapa novecentista, um novo sinal da sua presença decisiva nos destinos cruzados da técnica e da vida.

Considere-se, neste ponto, a seguinte passagem de Stephen Wilkinson e Eve Garrard como uma introdução direta ao atual clima científico e acadêmico em torno da efeitualidade eugênica. "A eugenia não parece ser imoral. Sendo o diagnóstico genético pré-implante, assim como outras formas de reprodução seletiva, algumas vezes tec- 
nicamente eugênicos, tal não basta para demonstrar que eles são errados" (Wilkinson \& Garrard, 2013, p. 11). O que significa essa ideia de que algumas técnicas poderão às vezes "ser tecnicamente eugênicas"? Há que lê-la em um plano diferente da simples cautela própria de quem reergue um discurso sobre aquilo de que a ciência não fala há setenta anos por motivo de um trauma histórico. A história da tecnociência não é apenas um conjunto de eventualidades, mas aponta as direções de uma onto-história, de uma história dos seres. Nas suas omissões, nos seus saltos e nos seus lapsos, todos os entes - vivos e técnicos - adquirem as suas figuras.

A eugenia é uma das formas mais agudas e prementes da sobreposição entre a técnica e o humano pelo trabalho da figura. O que significa que a amplitude do que fica em resto, do que age sem ser operativo, é enorme. A eugenia é uma falsa ciência, mas a sua falsidade é constantemente reintroduzida pelo efeito jurídico que a ela se agrega. Na eugenia, a purificação é indissociável de um juízo. Todo o juízo purifica e toda a purificação vem de um juízo, o que faz dela o oposto da comunidade, a sua impossibilidade. Ela faz da comunidade o lugar impossível de uma transcendência que toma cada um pela indiferença. Aquilo que passa entre as singularidades corpóreas e psíquicas é o que fica irreconhecível e é evacuado. Prerrogativa de um deus in absentia de quem a técnica vem, afinal, cumprir o desígnio. Ao contrário da medicina, que trata no corpo a ferida, a gangrena, o cancro, em oposição às medicinas sagradas, que tratam no espírito a possessão ou a acédia, a eugenia trata um agregado obscuro de males, uma acumulação simultaneamente histórica, social e metafísica de males. No fundo, a eugenia, que opera sempre pela adição metafísica, é a verdadeira medicina metafísica e está direcionada para os males que se acumulam como resto ativo da humanidade. Ela expropria o humano pelo próprio.

Se há algo que as tecnologias modernas e tardo-modernas foram explicitando, acelerando e hipertrofiando foi essa potência articulatória que exige operações que tornam os entes semelhantes e operações que os diferenciam. Hipertrofiadas e orientadas para a diferença humana, essas operações são, necessariamente, performativas no sentido linguístico: a semelhança e a diferença fazem-se aparentes no discurso e na sua metafísica. Na verdade, poderemos dizer que o discurso é o lugar onde aparecem a semelhança e a diferença. Antes do mais, a diferença do animal falante. Mas, como as técnicas operam sempre dentro do contexto de tropos, de estados de coisas e de mundos, haverá o maior interesse em verificar quais são as percepções históricas e simbólicas que parecem predominar nas nossas sociedades. Dominante hoje é a percepção 
de que a fabricação de novas coesões - novos organismos, novas redes - é aquilo que determina o poder da técnica. Operações pelas quais o que parecia separado, indiferente ou estranho torna-se integrado, diferente e familiar. A separação, pelo contrário, é uma condição que exige hoje, para ser mantida, um crescente número e uma maior complexidade de procedimentos técnicos e simbólicos. Diremos mais, a separação é aquele tipo de operação técnica que se manifesta hoje como técnica jurídica, enquanto elemento determinante, para que possa ser sustentada. Parece-nos que a cultura técnica do nosso tempo é, não somente integradora, mas inventora de integrações e articulações do que se faz autônomo. O que se passa é, contudo, mais complexo e continua a ser sustentado, simultaneamente, por operações de diferenciação e integração. Muitas das primeiras não são aparentes. Torna-se necessário, para compreendê-lo melhor, conhecer a história da eugenia.

No fechamento do livro de Hermínio Martins, Experimentum humanum, podemos ler um importante texto sobre a história da eugenia (Martins, 2011). Segui-loemos nas restantes páginas deste texto, já que a história da eugenia oferece o melhor guia para a obscura formação do complexo vida-técnica. A eugenia moderna é pensada e praticada no mundo ocidental moderno desde a década de 1870, tendo particular vigor, não apenas na Alemanha, mas também nos países demo-liberais anglo-saxônicos e nas democracias nórdicas. À semelhança de outros autores, Hermínio Martins distingue entre "eugenia positiva" e "eugenia negativa". 5 Elas são por ele definidas como "remediação e prevenção da disgenia", quer dizer, como processo que visa impedir que alguns grupos da população "tenham progênie", no primeiro caso, e como "promoção do aperfeiçoamento genético" (2011, p. 395), no segundo. Mesmo que essa distinção possa encontrar uma hipotética diferenciação processual e política em mecanismos de consentimento e de "valorização" do indivíduo, podemos detectar uma ironia implícita no seu uso. Haverá uma diferença entre a eugenia submetida a restrições e a eugenia sem restrições? E o que é uma restrição à eugenia? Em princípio, a restrição assume, na eugenia positiva, uma feição de "maximização do capital genético" das famílias (Martins, 2011, p. 396). Há aqui alguma equivalência com a visão do capital no capitalismo tatcheriano: um capital que está na esfera da vida privada é um existente

5 A propósito dessa diferença, será útil ler a seguinte passagem de Hermínio Martins, onde a "urgência" política dessas opções é bem compreendida. "O eugenismo sempre partilhou alguma coisa da dicotomia fundamental do apocalipticismo religioso, ou das ideologias seculares catastrofistas: ou o abismo ou a ascensão, tertium non datur. Ou deixa-se prosseguir a degradação do gene pool, inevitável na civilização humanitária, ou escolhe-se o caminho pelo progresso rápido, acelerado para níveis de qualidade (capital genético) das populações a caminho para o homo superior para níveis de inteligência cada vez mais altos. (...) Portanto, ou aplica-se a eugenia negativa imediatamente e em grande escala, sem preconceitos moralistas, ou aplica-se a eugenia positiva mais acelerada possível, para reduzir cada vez mais a proporção da população geneticamente inferior, não obstante a sua maior fertilidade" (Martins, 2011, p. 396). 
cujo crescimento e valorização nunca é corrompível porque corresponde a uma ontologia adquirida. Esse capital pertence a uma categoria do ser cujo incremento é, simultaneamente, uma preservação do estado de coisas. Evidentemente, essa opção conserva a diferença entre os gene-rich e os gene-poor, a não ser que "houvesse uma intervenção especial, suponho que com subsídios estatais" (p. 396), o que traz a socialdemocracia para o campo da eugenia positiva. Como sublinha Martins, a tese mais "simpática" que marca o eugenismo positivo é a de Alfred Russel Wallace, que estabelece uma equivalência entre a emancipação da mulher e a escolha dos melhores parceiros. Veríamos, assim, a eugenia tornar-se um movimento que integraria e reforçaria as conquistas civis do século $\mathrm{xx}$.

Aí, a eugenia tornar-se-ia humana no duplo sentido do termo: seria uma questão dos seres humanos e seria uma questão apropriada e legitimada pelo humanismo ocidental. Eugenia positiva e negativa resumem um constante entrecruzamento entre duas ontologias do Ocidente, a saber, aquela que institui a subordinação do agir ao ser e uma outra que faz depender o ser do agir. A dicotomia entre eugenia positiva e eugenia negativa parece, assim, do maior interesse, desde que não vejamos nela um sentido ético ou propriamente histórico, mas possamos entendê-la antes como a descrição do espectro zoopolítico e, portanto, ontológico da eugenia, a inerente plasticidade da sua aparição histórica. Assinale-se essa consciência na seguinte passagem de Hermínio Martins. "Historicamente, a eugenia negativa (coagida ou não) foi aplicada muito mais extensamente e mais sistematicamente em todos os países ocidentais do que a eugenia positiva, como também em países autoritários ou totalitários - até hoje" (p. 399). A seguir, Martins acrescenta que "os sonhos e visões da eugenia positiva estão a sofrer um período de euforia e ascensão". O que mudou? Não será tanto a eugenia que muda, mas a articulação do espectro político-técnico que aqui ganha consistência. As novas ciências biológicas vieram abrir um espectro muito largo do programa eugenista, a ponto de que, precisamente, este já não necessita de apresentar-se ligado a sua própria história (como subordinado a um programa racista, por exemplo). Há um devir imanente das escolhas eugênicas de que a saúde é o primeiro indicador. O corpo objeto da engenharia biológica adquire os traços da eugenia positiva por via de uma combinação complexa de dispositivos médicos e jurídicos. A engenharia biológica é sempre tomada como estratégia defensiva de um complexo de sistemas, à semelhança do discurso ocidental sobre a guerra. Mas se perguntarmos o que é defendido, ficaremos apenas com a vida como resposta (de que a defesa do "modo de vida" é uma das variantes). A vida aqui já não é a raça - que, aliás, nunca foi o tópico central na eugenia nazi -, mas a própria possibilidade catastrófica que a essa assiste de permanecer na indistinção entre vida animal e vida humana. Ora, o movimento metafísico a que a eugenia dá expressão é o afastamento do animal (recorrendo abundantemente ao seu material 
biológico). Quanto mais distantes nos encontramos da animalidade - por processos quer genéticos quer técnico-culturais - mais esse movimento acelera-se, fazendo-se mais instigador. A que podemos atribuir essa aceleração eugênica? Seria insuficiente dizer que tal seja atribuível à tecnociência. Devemo-la antes à conexão cada vez mais intrincada entre ser e agir, sendo o ponto nodal dessa conexão a vida dita humana. Nenhuma atualização do ser pode hoje deixar de ser a potenciação do agir. Dos processos ligados ao QI às estratégias educativas informatizadas, é sempre o agir que está em causa.

Pergunta-se: é a eugenia humana ou desumana? Ao contrário da visão comum que temos de outros processos técnicos, apercebemo-nos facilmente de que a eugenia é necessariamente humana $e$ inumana. É humana porque visa preservar e incrementar elementos que estamos habituados a designar como humanos, ou seja, a inteligência e a saúde, a resiliência e as capacidades de socialização. Mas faz isso a partir de uma dimensão que é alheia ao discurso humano, à construção do sujeito e a sua complexidade. Melhor, prefere outra complexidade a essa, historicamente dilemática. Por esse motivo, os elementos humanos que referimos tornam-se imediatamente os seus contrários, já que não estão submetidos às práticas linguísticas, culturais e éticas em que as sociedades humanas confiam. Aparecem submetidos à vida, pois é a vida que reabsorve todo o discurso, é a vida que se faz fonte única do discurso. Esse cruzamento da humanidade e da vida biológica é evocado pelas palavras de Robert Antelme em L'espèce humaine: "o pôr em questão a condição do homem provoca uma reivindicação quase biológica de pertença à espécie humana” (Antelme, 1957, p. 16). Dolorosa e estranha constatação de uma situação comum nos campos e nas democracias contemporâneas em que a vida torna-se a ultima ratio. Que fazemos com a vida em tais situações? Torna-se evidente que a eugenia aparece aqui como a possibilidade omnipresente de refazer uma linguagem a partir dessa voz branca que é a vida. Nesse quadro, a distinção entre eugenia positiva e negativa tenderá a desaparecer.

Outro fator será decisivo para esse desaparecimento. As tecnologias genéticas transitam hoje entre a sua aplicabilidade animal e a sua aplicabilidade humana. Tudo isso estabelece um quadro que é ainda mais problemático, em sentido ontológico, na sua orientação para a vida. O trabalho sobre a vida não humana transpõe para o interior da eugenia o movimento de que falamos acima, esse afastamento da posição biológica do humano em relação ao animal. Não se tratará já de um devir-humano pela eugenia, mas de um vir a si pela própria deslocação no interior do mapa genético e biológico. A posição do humano dentro da biosfera deverá tornar-se impossível de localizar, não porque o homem abandone a vida, mas porque se transforma em um ser capaz de passar pelas várias dimensões dos modos de existência: a terra e o céu, o humano e o divino, aproximando-se, como afirma Fabián Romandini (2010b), da condição do anjo e substituindo-se, no fim de contas, a este. 
Se a estudarmos mais de perto, poderemos verificar que o projeto da eugenia não é verdadeiramente orientado por uma representação do humano, mas guia-se, antes, pelas representações do animal ou do não humano. Só representando a animalidade será possível tomá-la como o lugar de que nos distanciamos. Claro que é o humano que é aí visto como contaminado pelo animal e, a partir dessa imagem, é trabalhado. A questão central da eugenia é a questão da animalidade. É o animal que referencia, na escala zoológica, um limite reconhecível do humano, já que o humano é entendido, em sentidos contraditórios, como ilimitado e incompleto. O animal não é aqui um problema das ciências positivas, mas deve ser visto do ponto de vista ontológico. A indecidibilidade do humano e do animal conduz a história da ontologia até Heidegger, e que não se pense que ela parte de uma afirmação gloriosa da diferença do humano. Desde o seu início, a fragilidade da distinctio humana funda uma longa sequência de antropotécnicas, de que a eugenia é, não apenas um prolongamento moderno, mas algo bem presente no centro da metafísica grega. De um modo geral, as antropotécnicas visam criar o humano, já que o homem é aquilo que vem da indecisão, da incompletude, do erro, do pecado ou da espectralidade (cf. Romandini, 2010b). Todas as narrativas da origem humana presentes nas fontes mítico-literárias do Ocidente dão conta dessa imperfeição ontológica do humano, a que corresponde a necessidade, também ela ontológica, da aparição das technai. A técnica paradigmática do imperfeito, sempre em risco de cair na animalidade, mas a ela arrancando o homem, é a eugenia. Mas como é demonstrado pelo dispositivo eugenista do nazismo, a eugenia não é uma técnica que possa ser singularizada, já que ela reaparece no centro dos processos históricos em que técnicas convergentes relançam o problema da incompletude humana. Essa observação permite-nos regressar à imbricação entre eugenia positiva e eugenia negativa, já que a eugenia é um saber e uma práxis a que sempre faltou um paradigma tecnocientífico, mas onde subsiste um modelo ontológico constante. Já era assim em Platão. A potência dessa ontologia alimenta-se, paradoxalmente, da debilidade técnica e científica do seu processo histórico.

Por essa razão, os dois maiores e mais duradouros domínios antropotécnicos são a medicina e o direito. No seu arco, estende-se o vazio de uma promessa do ser. Será necessário que, através de um processo sobre a biologia, torne-se evidente, juridicamente, a aparição do humano. Todo fracasso eugenista é a ocasião de um reforço metafísico da ontologia da incompletude humana através de uma nova deslocação nesse enorme arco do opus humanum. Não se coloca essa designação em oposição àquela de Hermínio Martins. Através dela expressamos o que há de performativo, mas também de historiográfico, ${ }^{6}$ no sentido de uma ontologia do agir, na eugenia ocidental. 
A experiência é um dos aspectos dessa ontologia. Contudo, lembre-se, o homem não é um ser disponível, mas aparece antes como o lugar (topos) da disponibilidade do ser, vindo a constituir um erro ou um enigma disponível. A sua definição biológica é acompanhada a par e passo pela sua definição jurídica, que lhe é contemporânea, sobretudo, quando lhe inventa uma origem e um fim (telos), o que, longe de caber no laboratório, faz do humano o próprio laboratório dos outros entes.

Sabemos que as políticas de eugenia positiva não deixam de recorrer à eugenia negativa, sendo também conhecido que a eugenia negativa, mesmo sob a forma do extermínio, dedica-se à investigação e desenvolvimento de formas positivas de eugenia. No contexto do terceiro Reich, as práticas médicas da SS são o exemplo disso. Embora aplicadas experimentalmente em sub-humanos (Untermenschen), muitas delas visavam, pelo menos hipoteticamente, o desenvolvimento de técnicas eugênicas na população germânica. Os campos tinham uma finalidade secreta ou não explicitada, o extermínio dos judeus e de outras categorias de sub-humanos, e uma finalidade expressa, que a historiografia tende a ignorar, a saúde pública da população alemã. Nos anos 1940, a entidade mais facilmente operável era o grupo étnico, sendo portanto a este que eram aplicadas as medidas públicas e secretas, positivas e negativas, decorrentes de uma biopolítica consequente nos seus efeitos visíveis e invisíveis.

Qual será a categoria que nos permita pensar as diferenças entre a eugenia que encontra restrições e aquela que não as tem? No Reich, curiosamente, as experiências efetuadas em sub-humanos encontravam nestes o analogon corrompido da raça superior. Se toda a experiência realizada em organismos vivos depende de um cálculo sobre a articulação de espécie e de categoria que tais organismos sustentam face ao nosso, caso do rato de laboratório, algo equivalente, mas profundamente diferente, acontecia nos "hospitais" de Auschwitz-Birkenau. Também aqui um cálculo ontológico, uma escala dos seres. Mas o judeu é aí um resto, não do humano, mas de uma corporeidade roubada ao ser. Uma aparência que remete ao que, nela, se faz irreconhecível, enquanto o rato simplesmente remete para uma analogia longínqua e inócua. O sub-humano é detentor de uma plasticidade ameaçadora, pois se assemelha aos homens, mas não é um deles. As variantes históricas da eugenia podem ser melhor reconhecidas se as colocarmos nessa escala gnóstica que divide os organismos entre aqueles que pertencem a este mundo e aqueles que lhe são estranhos. Será ainda o caso das supostas vivissecções e experiências biológicas conduzidas secretamente em extraterrestres durante a vaga de óvnis da Guerra Fria. O que demonstra que as experiências em organismos vivos são uma necessidade simbólica. Evidentemente, a eugenia negativa encontrará o seu acme progressivo desde as políticas de "eutanásia não consentida" (Martins, 2011, p. 395) na Alemanha dos anos 1920 (é ainda Weimar) até aos campos de extermínio, em pleno labor de 1941 a 1945 . 
O que terá levado Martins a escolher um texto sobre eugenia para encerrar um volume tão rico de perspectivas sobre os contextos tecnocientíficos das nossas existências? É a eugenia o topos decisivo no que concerne às relações entre civilização tecnológica e condição humana? Em espelho a essa questão, coloca-se outra: por que razão Martins abre o seu volume com um texto que tem o seu eixo no "gnosticismo tecnológico", aí lido como uma atividade que necessita da degradação ontológica da unidade do humano? Em termos gnósticos, realizar o possível tecnológico equivale a uma desconstrução do humano, não só do seu circunstancialismo, mas também da sua estrutura atual. De certo modo, a barreira ao conhecimento não é de ordem epistemológica, mas simplesmente ontológica. Tal como é, o ser humano vê limitada a sua condição e aquilo que pode alcançar. Por seu lado, a preocupação maior da eugenia foi sempre o aspecto reprodutivo dessa estrutura humana. Não é óbvio que a eugenia esteja limitada a aperfeiçoar as possibilidades reprodutoras que o aparelho sexual e a genética humana oferecem. Em algum momento, a eugenia é colocada perante uma ruptura, uma escolha ontológica decisiva: é a qualidade das populações algo que depende da seleção e preservação de um patrimônio pré-determinado ou deverá ela ser assegurada pela introdução de algum elemento que modifique as características ontológicas do humano?

Abstraindo do problema do humanismo, torna-se claro que a eugenia coloca o problema plástico do humano: com o que se parece um ser humano? Esta é, igualmente, uma pergunta gnóstica. Procura-se um modelo ideal, mas esse modelo permanece ignoto ou está contido em arcanos numéricos quase esotéricos (como é o caso do número geométrico em Platão). A eugenia deverá vir a operar na impossibilidade de reconstituir um modelo de ser humano. Impossibilitada de fazê-lo, ela deverá voltar-se para o seu fazer, quer dizer, para seu ofício, na medida em que este é uma combinatória do possível. Entendida dessa forma, a eugenia pode reivindicar toda e qualquer dimensão da sexualidade humana. Mesmo a reprodução natural, aquela por meio da cópula entre mulher e homem, obedece a esse imperativo no qual o que se faz é já o ser. É Ficino, reintrodutor do platonismo no Ocidente, quem fala da cópula como officium. Ora, a cópula permite-nos aprofundar a leitura do trabalho que Giorgio Agamben tem vindo a fazer na série Homo sacer. Se, no volume O poder soberano e a vida nua (1995), ele assinala, com a declaração de 1789, a entrada da zoé, enquanto vida nua, na ordem estrutural do Estado através do "puro fato do nascimento", em um volume quase vinte anos depois - Opus Dei, arqueologia do ofício -, Agamben aprofunda essa observação por meio de uma analítica da introdução na teologia cristã de um terceiro elemento entre a potencialidade e a atualidade (2011, p. 73). Progressivamente, "a subordinação do agir ao ser, que define a filosofia clássica, perde todo o seu sentido" (2011, p. 87). Tem início, naquilo que se constituirá como um traço característico da modernidade, o enten- 
dimento do ser como aquilo que se manifesta em ato, quer dizer, aquilo que é porque um agir aperfeiçoa o seu ser. Se a arte e a filosofia encontravam-se já constituídas nesse sentido, as ciências virão dar-lhe um impulso decisivo. Mas apenas a eugenia terá a possibilidade de constituir um agente "que age somente na medida em que ele é também efeito" (2011, p. 88).

Colocando ainda na mesa a organização do livro de Martins, pergunta-se: a influência gnóstica sobre a tecnociência moderna conduz, necessária e inelutavelmente, a uma modalidade da eugenia enquanto processo que estabelece uma adequatio entre o mundo e o seu habitante? Sinteticamente, podemos enumerar aqui alguns dos pressupostos gnósticos:

(a) insatisfação com a situação humana;

(b) o entendimento do mundo como um contexto hostil;

(c) a necessidade de um mundo adequado;

(d) a absoluta necessidade de recorrer à ação humana já que a ação divina encontra-se impossibilitada;

(e) a possibilidade de, pelo conhecimento, reabrir o ser e torná-lo disponível.

É por essa razão que a Gnose, mesmo na sua forma histórica, foi definida por alguns autores como uma tecnologia do ser. O gnóstico é aquele que só pode agir na medida em que vive do seu saber e é, paralelamente, aquele para quem a única fonte da ação é a manifestação desse saber. O gnóstico conhece a queda no mundo, o que ele aí é, e por meio desse conhecimento poderá evadir-se do mundo. Voltamos a sublinhar um curioso equívoco ontológico que parece percorrer o pensamento gnóstico: o ser e o agir tornam-se aí indecidíveis. Não podemos diferenciá-los, ou melhor, pretende-se que eles não sejam diferenciáveis. Nessa conjugação entre gnose e eugenia, joga-se o que chamamos - mas nisso não estamos sós - uma ontologia da operatividade do efeito. Nela, ser e agir confundem-se e interagem incessantemente. Com efeito, a herança aristotélica alimentou, durante séculos, a constituição de uma ontologia no espaço teológico e filosófico do cristianismo. Uma parte vital desse esforço, que exigia uma revisão aturada do aristotelismo, foi a definição de uma ontologia ressurrecional, determinante para a constituição das tecnologias dos entes no cristianismo. Aquilo de que a ontologia dispõe para determinar os limites dos entes são precisamente esses processos articulatórios, quer sejam naturais, sobrenaturais ou técnicos. Verifica-se que todo o limite ontológico pode ser ultrapassado ou modificado. É a articulação uma realização das coisas que acompanha uma realização do humano? Ou será uma propriedade das coisas que usa o homem? Ou, inversamente, a articulação é uma violação das coisas que realiza o homem? E o que dizer da ruptura dessa articulação? 
Embora o cristianismo tenha trazido o problema da vida à ontologia, parece-nos útil suspendê-lo nestas linhas finais, para, com Heidegger, lembrarmos que a pergunta "o que é uma coisa?" (Heidegger, 1971) encontra-se sempre já respondida. Do ponto de vista ontológico, não partimos da montagem de coisas, mas tão somente da coisa em si. Ora, a coisa em si - que é algo "dito" - é aquela que resiste a ser dita. A singularidade da ontologia reside nessa aparente contradição em que, considerando que a coisa é o que é, na verdade é ela a residência do mais indeterminado. Mas a indeterminação não é natural: o indeterminado é precisamente um ponto focal da metafísica. Diante de toda a pergunta pelo ser é a coisa que responde pela sua modalidade de presença. Ou seja, as coisas não só estão presentes, mas dizem algo da sua presença. Talvez não um discurso direto, mas há certamente aí uma afirmação, mesmo se ressoante, desviada, ventríloqua, abafada, distorcida. Chamando "coisa" a algo, antecipa-se um traço ontológico desse algo, emprestamos-lhe uma voz e condenamo-nos a ficar na dúvida essencial sobre a natureza dessa apropriação denotativa. Esse será o equívoco sobre a ontologia denotativa, ou seja, que se possa dizer algo a partir do ponto onde a coisa se encontra. A ontologia nunca denota nem poderia fazê-lo. Se o fizesse, estaria a dizer que cada coisa é, na sua presença acidental, o acidente substancial do ser. Acidente e substância encontrar-se-iam reconciliados ainda antes de estarem em oposição.

Toda a analítica de Martins necessita dessa presença da oposição naquilo a que chamamos técnica. É ela que permite a condução da técnica ao seu estádio gnóstico. O gnóstico depende desse paradoxo ontológico que afirma a recondução das coisas a um estádio anterior àquele da sua cisão ontológica (da diferença ontológica, diria Heidegger), quer dizer, anterior à inabilidade na presença das coisas, que se pode manifestar como uma inadequação relativa da sua matéria (hylé) em face a sua forma (morphé), ou como desencontro entre uma presença tomada singularmente e uma percepção que se multiplica. Esse estado de negação da tensão ontológica nas coisas é característico da tentação gnóstica, como bem percebeu Martins. Nesse sentido, as técnicas tomadas por uma impulsão gnóstica são aquelas que operam na reversão da diferença ontológica.

Essa rejeição gnóstica do "estado da coisa" não é apenas um posicionamento ontológico da coisa, mas é também moral. A coisa, tomada gnosticamente pela técnica, segrega uma moral. No sentido gnóstico, o objeto da técnica não é aquilo que é produzido por ela, mas aquilo que é produzido pela tecnicidade da sua moral. A técnica é, consequentemente, a recusa de permanecer na imperfeição, no inacabado. Cremos que o essencial das chamadas tecnologias inteligentes está ligado a essa capacidade dos objetos tecnológicos repararem a sua própria deficiência. Por outro lado, só tem sentido gnóstico aquilo que se reconhece a si mesmo como imperfeito e que é capaz de operar na própria memória de uma perfeição que lhe seja mnemonicamente indicada como própria. 
Toda a técnica está interessada em seu próprio bem, não no bem desse ente que dá pelo nome de humano. Mas os seres humanos confundem, voluntariamente ou não, o seu próprio bem com o bem que assiste às coisas e, de um modo particular, com o bem daquelas coisas que se encontram convocadas a um processo técnico. São cada vez mais as coisas que são convocadas, o que significa que cada vez mais coisas aspiram a um bem técnico. Claramente, a vida está diante dessa convocação, mas a sua resposta permanece incompreensível. De um modo geral, as técnicas não são desenvolvidas com vista ao bem do "utilizador", mas sim porque os processos técnicos já abertos visam um bem que, começando por ser próprio àquele, devém autônomo, e é esse bem da prossecução, curiosamente, aquele que é partilhado pela vida e pela técnica. Necessitaríamos de outro texto para confrontar a prossecução própria da técnica com a prossecução própria da vida. A eugenia explora a sua similitude ou a sua confusão? Talvez a nova eugenia assente, precisamente, nessa confusão que se faz similitude.@

Jorge Leandro Rosa

Instituto de Filosofia,

Universidade do Porto, Portugal.

jorgeleandro.rosa@gmail.com

\title{
The articulation that breaks beings: about life's exposure to ontological dispersion
}

\begin{abstract}
This article is about the possibility of renewing the understanding of eugenics in contemporary world. Biology and genetics are scientific resources of eugenics, but they are not alone at its philosophical core. This is the reason why we regard the ontology behind eugenics as our main concern. The status of eugenics as a practice is rapidly changing, and life is both the object and the hidden dimension of this change. Understood through the history of being(s), ontology's dispersion allows a renewed understanding of both humanity and animality. How can we understand that a fully recognized science at the beginning of the twentieth century became a silent practice of the twenty-first century? The dissemination of new genetic techniques and today's discretion with respect to eugenics appear to be connected within steps towards its rehabilitation. We are still at an early stage of our understanding of human genetics. There's no reason to think that such knowledge will not be explored through eugenics. After all, the plasticity of our human condition finds in it one of its possibilities.
\end{abstract}

KeYwords • Eugenics. Ontology. Life. 


\section{REFERÊNGIAS BIBLIOGRÁFIGAS}

Agamben, G. O poder soberano e a vida nua. Homo sacer. Lisboa: Presença, 1995.

Opus Dei. Archéologie de l'office. Paris: Seuil, 2011.

Antelme, R. L'espèce humanine. Paris: Gallimard, 1957.

Ellul, J. Le système technicien. Paris: Calmann-Lévy, 1977.

GLAD, J. Future human evolution: eugenics in the twenty-first century. Schuylkill Haven: Hermitage, 2008.

Heidegger, M. Qu'est-ce qu'une chose? Paris: Gallimard, 1971.

. La question de la technique. In: . Essais et conférences. Paris: Gallimard, 1990.

The fundamental concepts of metaphysics. World. Finitude. Solitude. Bloomington: Indiana University Press, 1995 .

LAmarck, J.-B. Hydrogéologie, ou Recherches sur l'influence qu'ont les eaux sur la surface du globe terrestre; sur les causes de l'existence du bassin des mers, de son déplacement et de son transport successif sur les différens points de la surface du globe; enfin sur les changemens que les corps vivans exercent sur la nature et l'état de cette surface. Paris: l'Auteur, Agasse et Maillard, (an X), 1802.

Malabou, C. Le change Heidegger. Paris: Léo Scheer. 2004.

Martins, H. Biologia e política: eugenismos de ontem e de hoje. In: Experimentum humanum. Civilização tecnológica e condição humana. Lisboa: Relógio d’Água, 2011. p. 390-4222.

Platão. Le politique. Paris: Gallimard, 1994.

Romandini, F. L. A comunidade dos espectros. I. Antropotecnia. Florianópolis: Cultura e Barbárie, $2010 \mathrm{a}$. Kyrios Christos: o dilema da nova soberania. In: . A comunidade dos espectros. I. Antropotecnia. Florianópolis: Cultura e Barbárie, 2010b. p. 103-55.

Rosa, J. L. Paulo e a tensão messiânica. Giorgio Agamben e o comentário como Ho nun kairos. Cadernos do Instituto São Tomás de Aquino, 22. Lisboa: ISTA. 2009.

Wilkinson, S. \& Garrard, E. Eugenics and the ethics of selective reproduction. 2013. Disponível em: <http:/ /www.keele.ac.uk/risocsci/currentactivities/theethicsofselective reproduction/>. Acesso em: 13 ago. 2014.

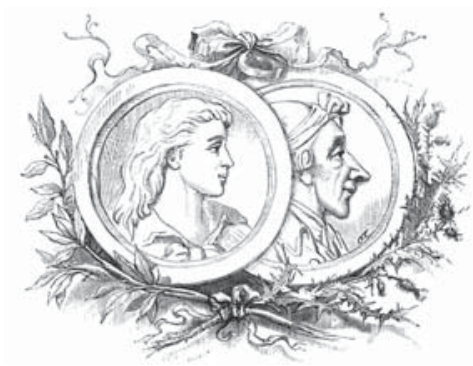

